\title{
ILDR2 wt Allele
}

National Cancer Institute

\section{Source}

National Cancer Institute. ILDR2 wt Allele. NCI Thesaurus. Code C156668.

Human ILDR2 wild-type allele is located in the vicinity of 1q24.1 and is approximately 93 $\mathrm{kb}$ in length. This allele, which encodes immunog lobulin-like domain-containing receptor 2 protein, may be involved in immunomodulation, Notch signaling, the response to glucose and cellular homeostasis. Overexpression of the gene may be associated with increased susceptibility for type 2 diabetes. 